\title{
A correspondência (quase secreta) de Theodoro - memória e silêncio, loucura e transgressão
}

\author{
Nádia Maria Weber Santos ${ }^{1}$
}

Résumé: Cet article présente les résultats d'une enquête qui visait à obtenir une sensibilité «à la marge», à savoir le déroulement d'un récit de vie d'un individu ordinaire (appelé Théodore), qui a été hospitalisé de Mai à Septembre 1937, à l'Hôpital psychiatrique São Pedro de Porto Alegre. Au cours de cette hospitalisation T. a écrit de nombreuses lettres et douze d'entre elles ont été trouvées dans le bulletin medical. De cette correspondance, on peut retracer l'histoire de 1' individu, son histoire dans l'hôpital et sa quête pour une place «dans le monde.» Personne bien élévée, mais qui souffrait de problèmes identifiés comme «folie» par sa famille (immigrants russes), il a laissé un vrai travail littéraire dans ses lettres, elles mêmes maintenues en détention à l'hôpital et dans les dossiers médicaux, qui n'ont jamais été rendu publiques. En plus de son histoire de vie, il discute le moment historique du monde (la guerre civile espagnole, par exemple), du Brésil, faisant de petites chroniques et critiques de la société, du clergé, de l'économie brésilienne. Par la suite, en rencontrant sa famille, s'est déroulé un nouveau regard et de nouvelles réflexions ont été faites: la mémoire de la famille, ses silences et souvenirs, ce qui correspond à la génération actuelle de ses enfants et neveux, sont également examinés dans cet article.

Mots-clés: Mémoire, Histoire de la sensibilité, Folie, Histoire et Littérature, Silence et transgression

Resumo: Este artigo tem como objetivo apresentar memórias e sensibilidades «à margem», isto é, mostrar o desdobramento de uma história de vida de um indivíduo ordinário (chamado Theodoro), hospitalizado de maio a setembro de 1937, no Hospital Psiquiátrico São Pedro de Porto Alegre (HPSP). Durante essa internação, ele escreveu muitas cartas e doze delas foram encontradas em seu prontuário médico. Dando um estatuto de literatura a essa correspondência, resgatamos sua história no hospital e sua busca por um lugar «no mundo". Inteligente e muito culto,

1 Doutora em História, Médica-Psiquiatra, Professora do Mestrado em Memória Social e Bens Culturais do Centro Universitário UNILASALLE. Coordenadora do GT de História Cultural da ANPUH-RS 2010-2012. 
mas sofrendo de problemas identificados como «loucura» por sua família (imigrantes russos) - e por isso, confinado em hospício - ele deixou uma verdadeira obra literária em suas cartas. Além de sua história de vida, ele discutia, nestas missivas, o momento histórico do mundo (a Guerra Civil Espanhola, por exemplo), do Brasil, fazendo pequenas crônicas e críticas da sociedade, do clero, da economia brasileira. A memória familiar, seus silêncios e lembranças, correspondendo atualmente à geração de seus filhos e sobrinhos, são também analisados neste artigo.

Palavras-chave: Memória, História da Sensibilidade, Loucura, História e Literatura, Silêncio e transgressão

\section{Introdução}

Este artigo apresenta os resultados críticos e reflexivos de uma longa pesquisa histórica, que teve como objetivo resgatar representações, memórias e "sensibilidades à margem" sobre a temática da loucura, e, neste caso, mostrar o desdobramento de uma história de vida de um indivíduo ordinário (chamado Theodoro), que foi hospitalizado de maio a setembro de 1937, no Hospital Psiquiátrico São Pedro de Porto Alegre. Durante essa internação, T. escreveu muitas cartas e doze delas foram encontradas nos prontuários médicos. Desta correspondência, podemos traçar a história dessa pessoa, a sua história no hospital e sua busca por um lugar "no mundo." Pessoa inteligente e muito culta, mas que sofria de problemas identificados como "loucura" por seus familiares, ele deixou uma verdadeira obra literária em suas cartas, que foram mantidas retidas no prontuário e nunca vieram a público. Além de sua história de vida, ele discutia o momento histórico do mundo (a Guerra Civil Espanhola, por exemplo), do Brasil, fazendo pequenas crônicas e críticas da sociedade, do clero, da economia brasileira.

Posteriormente em outra etapa de pesquisa, a partir do encontro de sua família, se desenrolou um novo olhar e novas reflexões foram feitas sobre esse indivíduo, que foi afastado (por ser considerado louco) pela sociedade em seu momento histórico. Entre os fatos mais relevantes descobertos através de entrevistas com sua família, soubemos que ele cometeu suicídio em 1938, ou seja, poucos meses após a alta hospitalar. Em nenhum momento sua família falou na internação psiquiátrica, fazendo-nos parecer que não sabiam deste episódio na vida de Theodoro. Com base no resgate das memórias da família, percebemos silêncios de memórias não reveladas e transgressões nesta vida cuja sensibilidade revelava mais do que a sociedade (incluindo sua família) poderia perceber naquela época.

TR (nome como ficou conhecido em meus escritos anteriores, usando suas iniciais por não poder identificá-lo) deixou uma obra escondida voluntariamente por aqueles que dele se aproximaram em vida. Não porque quisesse (ao contrário, ele queria ser escritor e historiador), mas porque reprimiram suas ideias rotulando-as como "loucas" - e é este debate que faremos neste trabalho. Desta forma, a partir de sua obra literária (conteúdo das cartas), no seu cruzamento com as entrevistas familiares, imigrantes russos, e com alguns teóricos da memória e da História Cultural (como Pollack, Halbwachs, Gondar, Ricoeur, Sarlo, Pesavento, José Murilo de Carvalho), teremos a oportunidade de reconstruir a história da sua vida e um pouco do momento da história coletiva daquele período. Memória, silêncios, esquecimentos, vestígios do passado, pistas do imaginário: uma intrincada rede de sentidos no resgate de memórias e de sensibilidades escondidas no passado... 


\section{As cartas de Theodoro e o hospício - Memória retida e transgressão : narrativas do} sensível

As cartas de Theodoro ainda dão frutos. Ricas cartas, prenhes de significado, escondendo memórias, silenciadas pela família e pela Medicina, mas transgredindo o momento histórico em que surgiram. Arquivando a própria vida ele nos fez deparar com vestígios de um passado, vestígios de memórias subjetivas. Artières revela: "arquivar a própria vida é se por no espelho, é contrapor à imagem social uma imagem íntima de si - próprio, e neste sentido o arquivamento do eu é uma prática de construção de si- mesmo e de resistência" (ARTIÈRES, 1998, p. 11).

Encontradas durante pesquisa anterior ${ }^{2}$ em um prontuário médico do Hospital Psiquiátrico São Pedro de Porto Alegre, este conjunto de correspondência revela muito mais do que a Medicina da época poderia pensar ou mesmo compreender. Rotulado como louco, TR sabia o que queria, pensava muito, era um inesgotável leitor de obras de filosofia, história, literatura e até psicanálise. Lia e escrevia também em alemão.

Mas à revelia de tudo isto, foi confinado em hospício durante quatro meses (maio a setembro de 1937) com diagnóstico de parafrenia. ${ }^{3}$ Em uma internação paga pela família, ou seja, diferenciada da maioria dos demais doentes (que em geral eram indigentes ou muito pobres) Theodoro recebia jornais para ler e, às vezes, papel para escrever. Seu pai e irmão, responsáveis por sua internação naquele momento, referiram ao médico que fez a "baixa hospitalar", que ele lia e escrevia muito, tendo várias ideias diferentes dos demais e isto era o motivo de sua loucura. ${ }^{4}$

Ele tinha 34 anos quando foi submetido a esta internação psiquiátrica. Era casado, pai de um filho de um ano de idade, tendo ocorrido um natimorto em gravidez anterior de sua esposa.

2 Sucintamente, descrevo as três etapas principais em que foram trabalhadas o conjunto desta correspondência: $1^{\text {a }}$ etapa - durante o mestrado em História na UFRGS (1998-2000), pesquisando prontuários psiquiátricos no APRS (Arquivo Público do Estado RS) do HPSP (Hospital Psiquiátrico São Pedro), encontrei, guardado em uma caixa extemporânea de 1898, um prontuário do ano de 1937 com 12 cartas e um versinho, aleatoriamente guardados, pertencentes a um só paciente - a quem chamei TR, internado de maio a setembro de 1937 - material este que consta na dissertação de mestrado (publicado em SANTOS, 2005); $2^{\mathrm{a}}$ etapa - dando um estatuto de literatura a este conjunto de missivas, foi traçado um paralelo com outros dois corpos literários e documentais (Rocha Pombo e Lima Barreto) que versavam também sobre loucura e internações psiquiátricas, perfazendo este material a tese de doutorado em História (2001-2005, também na UFRGS) sobre sensibilidades da loucura na literatura brasileira no início do século XX (publicado em SANTOS, 2008); $3^{\text {a }}$ etapa buscou-se reconhecer a vida de TR fora do manicômio, naquele mesmo período histórico, em uma pesquisa intitulada "Sensibilidades à margem" (2006-2008), coordenada pela professora Sandra Jatahy Pesavento, no âmbito do Núcleo de pesquisa em História (NPH), vinculado ao Departamento de História da UFRGS. O conjunto desta correspondência existe apenas na íntegra como anexo da tese de doutorado intitulada Histórias de sensibilidades: espaços e narrativas da loucura em três tempos - Brasil 1905, 1020, 1937. Tese de Doutorado. IFCH - PPG em História. UFRGS. 2005. 397 p., depositada na biblioteca setorial do IFCH da UFRGS, tomo II (anexos).

3 Parafrenia, termo cunhado no final do século XIX, era tradicionalmente utilizado na Medicina Psquiátrica, já no XX, para denominar as síndromes delirantes crônicas, que poderiam ou não evoluir para Esquizofrenia. Nos manuais psiquiátricos contemporâneos, é definida como um transtorno que inicia após os trinta anos de idade, e é caracterizado por apresentar um delírio insidioso, de base alucinatória, mal sistematizado, de fundo persecutório. É uma doença que evolui cronicamente, não dando espaço ao embrutecimento característico dos esquizofrênicos.

4 Todos estes dados foram retirados do Prontuário Médico de 1937, n. 7381, do Hospital Psiquiátrico São Pedro de Porto Alegre, onde constam as cartas do paciente TR (arquivado no Arquivo Público do Estado do Rio Grande do Sul). 
Na baixa deste paciente o médico descreveu-o como "tranquilo, ar de imperiosidade, sorriso irônico; diz o paciente sentir fraqueza na cabeça ao que devia excesso de trabalho mental e preocupações; é da profissão de padeiro; dedica-se desde algum tempo a estudar correntes philosóphicas, religião, política. Uma noite teve uma intuição mystica que lhe revelou o seu destino. Prevê acontecimentos futuros: a guerra da Espanha foi uma de suas previsões. Não tem quase afetividade: da própria internação não se queixa"(sic). ${ }^{5}$

Estava escrito no prontuário que era de origem alemã, procedente de Canoas (que na época pertencia ao $4^{\circ}$ Distrito de Gravataí) e de família de comerciantes com relativas posses. No encaminhamento feito pelo delegado de Canoas ${ }^{6}$ já se revela este fato: “... conforme vontade da família sua internação correrá por conta própria.” Posteriormente, descobrimos que sua família, embora falasse alemão, eram considerados imigrantes russos, vindos de Lodz (Polônia) no final do século XIX. ${ }^{7}$

No "Certificado de Internação", assinado por médico da cidade de procedência (às vezes eram médicos da própria delegacia, outras vezes, de hospitais da cidade), estava escrito: "ideias de grandeza, absurdas e extravagantes, insônia".

A partir do relatado nos "Dados Comemorativos" 8 conseguimos apreender as seguintes informações, sobre a história pregressa do paciente, dadas pelo pai e irmão do paciente, no dia da baixa hospitalar: TR tinha ambos os pais vivos, era o primeiro dos oito filhos deste casal, a gravidez e o parto transcorreram normais e este último foi "a termo" (no prazo certo). Tinha quatro irmãos vivos e três outros morreram em tenra idade. Sobre os antecedentes hereditários e colaterais, quando questionados se havia casos na família de alienação mental, responderam que um tio avô do paciente era alienado. Não havia outros casos (na família) de doenças crônicas, suicidas, homicidas ou portadores de afecções do Sistema Nervoso.

Sobre os antecedentes pessoais, TR não teve maiores problemas na primeira infância e adolescência, exceto um ferimento na perna em jogo de futebol. Na idade adulta sofria dos intestinos (?) e contraiu sífilis e gonorréia aos 24 anos, tendo feito tratamento adequado com "injeções". Não fazia uso de bebidas alcoólicas nem outras substâncias tóxicas. Sua inteligência era normal antes da moléstia atual; seu caráter era alegre e instável (as opções oferecidas no questionário eram: alegria ou tristeza, otimismo ou pessimismo ou ainda instável). Era uma pessoa desconfiada, impressionável, não era violento, nem impulsivo. Não o caracterizaram como mentiroso, simulador, inafetivo e brutal, nem pervertido sexualmente.

Ao serem inqueridos sobre a "doença atual”, deram as seguintes respostas: a causa desta era atribuída a desgostos familiares e ciúmes. Apresentava mania de grandeza, escrevia muito, tinha ideias extravagantes. Sofria de insônia, não comia mais. Havia uns três anos teve ideias suicidas, mas não concretizou nenhum ato neste sentido. Nunca apresentou outras reações anti-sociais. Sobre sinais neurológicos observados (crises epiléticas, perturbações da palavra, etc.), responderam que TR tinha "ataques" (sem outra especificação

\footnotetext{
5 Prontuário 7381, APRS. Mantive a ortografia original em todos os documentos, fato este relevante para compreendermos as ideias e a personalidade de TR, uma vez que seu português escrito era rico e revelador.

6 Esta era uma das formas antigas de fazerem encaminhamentos de pacientes a um hospital psiquiátrico, ou seja, pela delegacia de polícia. Para maiores detalhes ver SANTOS (2005), capítulo 2.

7 Retornaremos a este ponto na segunda parte do artigo.

8 Os "Dados Comemorativos", espécie de anamnese que era empregada nesta época, eram preenchidos no HPSP, muitas vezes, pela assistente social que entrevistava o familiar que trazia o doente ao hospital, e não pelos médicos. Este fato é sugestivo do quanto os médicos desta época não davam importância à história pessoal de um paciente. Todo este material encontra-se arquivado no prontuário médico.
} 
de que tipo). Vinha se tratando há muito tempo, mas também não informaram onde, nem como, nem há quanto tempo fazia. Às perguntas sobre se foi tentada cura por meios extramédicos, se já havia apresentado doença mental anteriormente, ou se teve internações em outros Sanatórios, não havia resposta escrita.

Na resenha médico- social, podemos detectar que TR casou- se aos 31 anos, com moça de 18. Teve uma primeira filha que faleceu com 1 ano. $\mathrm{Na}$ época da internação tinha um filho vivo, de 1 ano de idade. Sua juventude transcorreu em vida familiar, sem problemas. Era instruído, mas não informaram o grau de escolaridade, nem como era sua relação com os mestres e condiscípulos. Comportou-se bem no serviço militar e "levou um tiro de guerra". Sua ocupação sempre foi no comércio, não teve insucessos na vida prática; nunca esteve em prisões nem sofreu processos judiciais. Não teve recentemente abalos morais. A situação financeira da família era regular. Suas leituras de predileção eram jornais políticos. Era protestante, mas não praticava esta religião, conforme resposta de seu pai. À pergunta: “entregava-se a práticas de espiritismo, batuque ou feitiçarias?”, não houve resposta.

Estes dados informados pelos familiares, traçam, já, uma certa representação da doença, desde o ponto de vista da família, pois muitas coisas que o paciente relata de sua vida nas cartas que escreve não foram aí mencionadas, não foram respondidas. Além do mais, fica explícito o que eles supunham ser a causa da "doença atual".

No seu prontuário não há muitas especificações (que em geral aparecem nas evoluções dos médicos) do seu estado mental no hospital, a despeito dos quatro meses em que lá permaneceu. Há nove "evoluções" do médico, nada explicativas, somente assinando algum medicamento administrado, ou dando conta de uma agressão por ele sofrida na enfermaria, ou dando-lhe alta ("alta para ter tratamento em casa").

Não há especificação sobre o tratamento administrado, mas há no final do primeiro mês de internação, uma "evolução" onde se lê: "Transferido para secção de terapêutica". Embora não tenhamos encontrado nenhuma referência na papeleta médica sobre o método empregado neste paciente, ele era sifilítico (tinha o exame laboratorial de Wasserman positivo), o que nos faz pensar, pelo menos, em Malarioterapia, que era o tratamento preferencial nesta época para este tipo de doença.

Assim, este "caso" pareceu-nos distinto de outros, por terem sido encontradas no prontuário treze cartas (doze cartas e um versinho) ${ }^{9}$ escritas pelo próprio paciente durante sua internação. Não é preciso frisar que estas cartas nunca chegaram a seus destinatários... Embora seu diagnóstico tenha sido "paraphrenia", antigo, o conteúdo destas cartas talvez menos tenha a ver com "delírios" e muito com a própria história de vida de seu autor. Eram cartas em geral de muitas páginas, escritas na sua maioria em papel almaço, dirigidas a um suposto "amigo", a editores de jornais, artigos para a imprensa (há um cujo título é "A avareza" e versa sobre o problema da avareza no mundo contemporâneo, que para ele era "uma das qualidades mais desprezíveis que o ser humano adquire e que está na vanguarda

\footnotetext{
$9 \mathrm{Na}$ pesquisa de arquivo, ao serem encontradas estas missivas, optou-se por dispô-las na ordem das datas em que foram escritas pelo paciente e não na ordem aleatória em que foram encontradas e arquivadas na papeleta. Três delas foram encontradas sem data, então foram colocadas em ordem pelo contexto ou "gancho" que o paciente deixou nas anteriores. Apenas uma delas e o "versinho' foram deixadas ao final, pois não foi possível correlacionar o contexto diretamente com alguma outra. A carta em alemão, em suas duas versões foram mantidas no original, com a respectiva tradução (feita por nós) ao lado. Algumas palavras em alemão ficaram obscuras ao tradutor, sendo pouco compreensíveis em seu contexto. Optamos, então, por deixar entre parênteses a tradução literal da palavra ou frase.
} 


\section{Conexão Letras}

do mundo"), desabafos "filosóficos" ("Meditações e previsões sobre o futuro") $)^{10}$, bem como aquelas dirigidas a "personalidades" de destaque da época como o Arcebispo Metropolitano e o Governador do Estado do Rio Grande do Sul. Algumas cartas são importantes, no sentido de ele contar sobre os problemas que teve com o pai e a família.

Ele apresentava, ao que se lê nestas várias cartas, ideias definidas sobre a religião católica, mas coloca-se como cristão (e não católico). Deixa transparecer uma certa admiração pelo nazismo e pela pessoa de Hitler e foi adepto do integralismo e do positivismo. Queria a paz no mundo, embora seu mundo interno não vivesse em paz. Ao mesmo tempo, ele diz-se ex-integralista, refere a si mesmo como um judas, ou assemelha-se a Deus, e briga com a Igreja Católica e seus padres. Ama e odeia ao mesmo tempo: "Apaixonado por vós, vos odeio, porque pregais na igreja o cúmulo da imperfeição-perfeita.” 11

Esta dualidade de sentimentos e opiniões perpassam todas as cartas, o que é típico na sua condição patológica do momento (cisão psíquica). Neste sentido, os oxímoros e as metáforas com símbolos de opostos enriquecem seus escritos... Para dar conta do que quer transmitir, alguma pitada de ironia e a sátira são também ingredientes constantes. Cabe ainda ressaltar que, embora esteja preenchido nos dados de identificação da papeleta médica que seu grau de instrução é secundário, ele escreve muito bem, num português corretíssimo para a época, em todos os sentidos (tanto o formal, quanto o coloquial). Notamos, também, a partir do conteúdo da carta 4, que este homem queria ser um escritor, ou pelo menos era escrevendo que ele se sentia livre...

Suas opiniões não estão aqui para serem julgadas se certas ou erradas. Importa constatar que, para nós, elas não representam tão simples e necessariamente "ideias delirantes", pois elas retratam uma realidade, tanto interna (psicológica), quanto externa a ele próprio, como veremos adiante.

Ao debruçar-me sobre os doentes e seu destino, compreendera que as ideias de perseguição e as alucinações se formam em torno de um núcleo significativo. No fundo, há os dramas de uma vida, de uma esperança, de um desejo. Se não lhes compreendemos o sentido, é uma falha nossa. Nessas circunstâncias, compreendi pela primeira vez que na psicose jaz e se oculta uma psicologia geral da personalidade e nela se encontram todos os eternos incuráveis, obtusos, apáticos, se agita mais vida e sentido do que pensamos. No fundo, não descobrimos no doente mental nada de novo ou de desconhecido; encontramos nele as bases de nossa própria natureza... (JUNG, 1984, p. 117).

Conforme uma das cartas (carta número 11) ele foi afastado do negócio da família (padaria), embora as ideias que revertessem em lucro fossem suas, e relata que seu pai não gostava que ele passasse bom tempo de sua vida escrevendo ("isto era loucura") e lendo filosofia e outros assuntos como política e religião.

Existem, também, cartas que são verdadeiros poemas, com depoimentos desesperados, de quem está sofrendo e também passando por uma internação psiquiátrica, tendo contato com a realidade diária e aviltante de um hospício ("a todo instante sou interrompido por loucos que, ora me pedem cigarro, ora fogo, ora a penna. Para dizer-vos basta que estou escrevendo encostado da latrina e de cigarro na boca,..." - carta 3; "ando seboso, quando vão me tirar daqui?"; "aqui no hospital começo a ver fantasmas..."- carta 4). Com frequência, ele deixa transparecer em seus desabafos, a indignação sobre a falta de condições,

10 Note-se que ele escreve no momento da ascensão dos regimes fascista e nazista no mundo e, aqui no Brasil irá começar o 'Estado Novo'.

11 Carta 3, endereçada ao Arcebispo Metropolitano Dom João Becker. 
lá dentro mesmo do hospital, de receber um pouco de papel para escrever (“...aqui nem a muque dão-me papel; Regime de hospital..." - carta 9; "rogo desculpar-me o feitio desta que é cara como tudo, aqui no hospital, onde estou e tenho que lutar com sérias dificuldades para adquirir um pouco de papel e tinta na altura, pois crêem que sou maníaco" - carta 7). Mas não deixa de admitir, em outros momentos, que está doente e precisa de tratamento (carta 6), quando diz, com ironia: “...attestando o meu estado de hyper-excitação nervosa, que claramente transparece naqueles versinhos rudes, pelo facto de reviver dias amargos e estar actualmente adoentado e em tratamento achando-me sob o açoite da medicina que desequilibra para equilibrar...".

Estamos diante de um material, narrativas, prenhe de sensibilidades, e, portanto, de sentido, e que revelam mais do que escondem, como se poderia imaginar ao aceitar-se a proposição de que as sensibilidades são intangíveis e não representáveis. A imaginação criadora, da qual também nos fala Paul Ricoeur a respeito da construção das narrativas históricas, é ingrediente intrínseco desta narrativa.

As sensibilidades se apresentam, portanto, como operações imaginárias de sentido e de representações do mundo, que conseguem tornar presente uma ausência e produzir, pela força do pensamento, uma experiência sensível do acontecido (memória). O sentimento faz perdurar a sensação e reproduzir esta interação com a realidade. A força da imaginação, em sua capacidade tanto mimética como criativa, está presente no processo de tradução da experiência humana (PESAVENTO, 2007, p. 15).

Escrever e ler eram duas ações que acompanhavam-no, desde menino. Seu pai relatou que o filho lia muito, e sua leitura predileta eram jornais políticos. Já TR diz, ao médico, que se dedica a estudar correntes filosóficas, religiosas e políticas há muito tempo. O que para um é sinal de loucura, para outro é um genuíno interesse pelo conhecimento. Eram atividades levadas a sério por ele, e em nenhum momento deixa transparecer que serviam como "uma boa atividade recreativa", como o queriam os psiquiatras da época.

É certo que ler - assim como escrever - requer concentração, atenção, um esforço. É muito feliz a metáfora utilizada por Kafka quando se refere a livros: "Um livro deve ser um machado para quebrar os mares congelados de nossas almas". ${ }^{12}$

Compartilha-se da noção, como se fosse uma visão de mundo, que a leitura, assim como a escritura, é um dos personagens principais na formação de uma personalidade, bem como na estruturação da relação com o mundo que a cerca. Em outras palavras, ler - e escrever - fortalece o "caráter" pessoal, bem como os laços sociais do indivíduo com o meio que o circunda, e mais ainda, promove a ponte com as reflexões mais profundas, aquelas que quebram o gelo da alma.

Ele amava ler e escrever. E isso sabia fazer muito bem; TR usou o machado kafkiano para desbravar o mais íntimo de sua psique, de sua alma. Estas cartas são testemunho sensível, de uma psique que sofria ... Mas, também, são verdadeiros depoimentos de uma época, sensibilidade fina que traz até nós dor, sofrimento e... reflexão.

Assim, TR recuperou várias discussões, internas e externas à psiquiatra de sua época, bem como construiu, desde dentro de seus delírios - a partir daqui já caracterizados como imagens simbólicas de conteúdos que vinham do inconsciente - uma visão própria sobre a loucura - e também sobre sua loucura - e sobre alguns "acontecimentos históricos" do momento.

12 Excerto de uma carta, provavelmente de 1903, de Franz Kafka a seu amigo de infância, o historiador da arte, Oscar Pollak. In: Escritos sobre el arte de escribir. Madrid: Ediciones Fuentetaja, 2004. 
Suas cartas são, também, repletas de símbolos, metáforas que o inconsciente produz, formando imagens psíquicas. Estas imagens, simbólicas, revelam mais que escondem, elas demonstram vida, e não doença - como o queria Freud e seus seguidores - na alma humana.

E são elas que nos conduzem, pelo caminho de TR, um anônimo, que foi padeiro e saboeiro, que lia muito e que se lançou na vida também através de seus escritos, e não foi reconhecido - publicamente, como gostaria - no seu tempo, nem no depois ... a não ser pela pesquisa histórica aqui relatada.

O indivíduo é a realidade única. Quanto mais nos afastamos dele e nos aproximamos de ideias abstratas sobre o homo sapiens mais probabilidades temos de erros. Nesta época de convulsões sociais e drásticas mudanças é importante sabermos mais a respeito do ser humano, pois muito depende de suas qualidades mentais e morais. Para observarmos as coisas na sua justa perspectiva precisamos, porém, entender tanto o passado do homem como o seu presente. Daí a importância essencial (e social) de compreendermos mitos e símbolos (JUNG, 1983, p. 58). ${ }^{13}$

Pelo cunho do presente artigo, será impossível colocar todas as suas cartas in extenso, porém, arrisco neste breve espaço, colocar alguns excertos delas, uma vez que são desconhecidas do público leitor como um todo. As partes escolhidas referem-se a questões importantes, pessoais e sociais, discutidas por Theodoro em seus escritos auto-referenciais, em seu movimento de "arquivar a própria vida".

\section{CARTA $1{ }^{14}$}

Ilmo Sr.

Vianna Moog

Correio do Povo

Li tua chronica da semana passada e estive ancioso por responde-la mas até hoje não tive oportunidade para fazel-o. Aqui em Teheran como tu sabes, a base fundamental, o regime interno é negar-se tudo, dando-se tudo, é nesta negação que reside a meu vêr, todo amor ao nosso próximo, do nosso ser. Foi um imenso prazer constatar que agora estás no Brasil estudando os costumes político- financeiros deste paiz onde como já disseste noutra carta ninguém obedece e tudo corre como num aranjada assim sonho de 1001 noites...Tu bem sabes meu precioso amigo que nunca tive a ventura de transpôr as fronteiras de nossa querida Persia, terra que tu como bom persa que és, e não deixarás de ser para isso conheço-te sobejamente, terra que para ti, para mim e para todo bom Persa que até hoje conseguimos aliar ao nosso ideal sagrado, representa o que todo Persa pensador ou não mais anceia, é ter uma

13 Jung terminou de escrever este texto, que compõe o primeiro capítulo do livro, dez dias antes de sua morte, em junho de 1961. Na introdução desta obra, o coordenador John Freeman escreve: "O pensamento de Jung coloriu o mundo da psicologia moderna muito mais intensamente do que percebem aqueles que possuem conhecimentos superficiais da matéria. Termos como, por exemplo, "introvertido", "extrovertido", "complexo" e "arquétipo" são todos conceitos seus que outros tomam de empréstimo e muitas vezes empregam mal. Mas a sua mais notável contribuição ao conhecimento psicológico é o conceito de inconsciente - não (à maneira de Freud) como uma espécie de "quarto de despejos" dos desejos reprimidos, mas como um mundo que é parte tão vital e real da vida de um indivíduo quanto o é o mundo consciente e "meditador" do ego. E infinitamente mais amplo e mais rico. A linguagem e as "pessoas" do inconsciente são símbolos, e os meios de comunicação com este mundo são os sonhos." E também, acrescenta-se, as imagens criativas dos escritos, literaturas, obras plásticas em geral e criações científicas e filosóficas.

14 Aqui, opto em manter a grafia original, conforme transcrição da carta de número 1 (por mim arranjada assim, ao colocá-las, todas, em uma ordem de datas e sentidos/significados). 
pátria livre do jugo extrangeiro, liberta por e em si mesma. Ah! meu caro Rustan como me sinto feliz nesta querida Teheran, aqui tudo é poesia e todos são poetas e se vencem as mais difficeis barreiras que se antepõe a cada indivíduo durante a peregrinação que faz dentro do próprio coração, de sua alma, do seu eu. Estou mais ou menos ao par do momento político que vive o Brasil, terra que ora visitas, também conheço perfeitamente o eixo político que creou uma verdadeira confusão de ideias, que não é exagero dizer, em todos paizes do universo. Caro amigo, sinto e lastimo imensamente que o Brasil não queira se orientar pelo livro mais sagrado de nossa terra e de todo mundo, que foi escripto com o próprio sangue do grande propheta que morreu pregado na cruz de Gotgotha, cuja vida foi ensinar a cada habitante deste mísero planeta o que mais nobre e belo o homem, uma consciencia sã de que nasceu para ser feliz e perfeito.

Liberdade doce liberdade, liberta-nos do jugo extrangeiro e de nós próprios.

Quem é que nos pode libertar do jugo extrangeiro e de nós mesmos? A Igreja!...porque já não o fez?...

Que grandes heróes e que grandes covardes são os padres! Porque não seguem o exemplo de nosso grande General Osório que dissera, "A minha maior honra será, mesmo depois de morto, quando eu souber que os povos do Universo queimaram seus arsenais".

Meu caro amigo como vês transportei-me em espírito da nossa Teheran ao Brasil e estou contigo onde estiveres, no Rio de Janeiro ou em Porto Alegre e tenho me interessado tanto pelo Brasil, que estudei minuciosamente sua história; que povo heróico! Um. fremito de entusiasmo perpassa todo meu ser e te juro pelo sangue do meu sangue que hei de escrever em nosso idioma a história dessa grande nação de além mar. Depois voltarei ao meu ofício de saboeiro, de que sou profundo conhecedor, a fórmula que me deste por carta dá sabão é magnífico e tem causado expanto nos meios scientíficos de nosso paiz, tanto que já tem tido franca aceitação pelo paes da medicina, que hoje já não vacilam empregá-lo nos casos em que certas circunstâncias o requerem. Mas a fórmula, meu caro eu não vendo por preço nenhum, fica entre nós.

A seguir escreverei uma carta ao Arcebispo D. João Becker de Porto Alegre, cuja cópia te enviarei incontinenti, quero transmitir ao grande teólogo, que é o modo como nós, os Persianos, interpretam a paz de uma nação e os remedios para consegui-la. Com a carta ao Revmo. Arcebispo termina a obra que não é minha e sim do grande Deus todo poderoso que a escreve por minhas mãos. Teu sincero amigo Iben, Teheran

Nesta primeira carta de Theodoro, ele se utiliza do expediente das Cartas Persas, crônicas jornalísticas escritas por Vianna Moog e publicadas no periódico Correio de Povo de Porto Alegre nesta época (em alguns meses de 1937 e depois copiladas em livro pelo autor). TR as lia no jornal e criativamente expressava seu dia-a-dia no hospício a partir deste escrito: o que ele fazia, daria para dizer, é quase como uma "crônica de hospício". Revelando aos poucos seu descontentamento com a internação e com a família, que o chamava de louco, não acreditava no que fazia e dizia, impondo que saísse do negócio familiar.

Adianto aqui, que na segunda parte deste artigo, os leitores terão oportunidade de ver como estas ideias são corroboradas por seus filhos, entrevistados por mim, em uma etapa mais recente desta pesquisa (ano de 2007), onde colocam que sua mãe lhes dizia como os tios (irmãos de TR e cunhados de sua esposa) falavam dele e o que eles ouvem, atualmente, dos primos.

Também é nesta carta que ele refere pela primeira vez aquilo que talvez seja um dos motivos de seu adoecimento, ou seja, uma relação de amor e ódio com algum padre da igreja ("Que grandes heróes e que grandes covardes são os padres!') história esta depreendida pela leitura e análise da obra como um todo. ${ }^{15}$

15 Remeto os leitores à obras (SANTOS, 2005) e (SANTOS, 2008), onde as cartas de TR foram interpretadas neste aspecto. 
Há uma carta escrita em alemão, endereçada a Hitler, onde consta uma confissão de fatos acontecidos a ele (foi seduzido por padres da igreja). Existem duas versões desta carta, como se uma (carta 5) fosse o rascunho e a outra aquela que deveria ser enviada (carta 4). Na primeira (carta 5) consta a confissão, na segunda (carta 4) não. Comparando com as outras cartas em português, encontramos nestas em alemão conteúdos semelhantes ou aproximados, dados estes que nos serviram de pistas para formularmos a história deste paciente e os problemas pelos quais estava passando neste momento específico de crise.

Assim, a carta 4 ("A confissão") tornou-se a mais importante deste conjunto, na medida em que retrata, através do imaginário do doente, os conteúdos psicológicos que o afligem. O simbolismo que nesta aparece (e é aquela que tem o "tom" mais "delirante"), tanto ao nível de conteúdos pessoais como arquetípicos, revelam aos poucos, toda a "trama" que sua vida teceu, até desembocar na "loucura", na sua dissociação psíquica. Como se fosse um filme passando diante de nossos olhos, aponta para a dualidade de sentimentos, para um drama não compreendido de um homem que manteve relações íntimas com um padre, a quem ele possivelmente amou e odiou... Esta carta apresenta a história psicológica e sensível de TR, história esta que faz a síntese entre a história pessoal e a história coletiva.

Estas duas partes em alemão, está disposta como segue:

Hospital de alienados mentais:

Sabbado, 26 de junho de 1937.

PS: Queiram transmittir à Sua Excellencia snr. Adolph Hitler as minhas escusas, por ter lhe furtado o padre. Tenho vontade de condecorar o meu grande bemfeitor. Aqui há um italiano que fez uma chinella estrambolica qualquer, roubo-a e mandarei à allemanha (a chinella é feita de galhinhos de sinamomo) e (...) juntarei uma dedicatória como segue.

(A carta que se segue é uma cópia da carta escrita posteriormente, no dia seguinte- carta 5. É um enxerto onde a última parte da original (digitada em itálico na carta 5), que se configura como uma confissão, foi nesta omitida pelo autor. Por seu caráter confessional, mas sobretudo pelo possível significado de tal omissão, este trecho será de grande importância para as nossas considerações analíticas. Como talvez tivesse o intuito de enviar esta e não a outra, foi omitida a última parte daquela )

$\begin{array}{ll}\text { Seiner Excellenz } & \text { Sua Excelência }{ }^{16} \\ \text { Herrn Adolf Hitler } & \text { Sr. Adolf Hitler } \\ \text { Dieses ding ist für den Mann } & \text { Esta coisa é para o homem } \\ \text { Der diesen Schlappen tragen kann } & \text { Que pode trazer este (pano) } \\ \text { Er hat Ihm gekrieg den Pfaffen } & \text { (Ele o enganou o "padreco") } \\ \text { Weil Er dat Biest konnte Affen } & \text { Porque ele pode enganar a Besta } \\ \text { Ich schick es Ihm mit allem Dreck } & \text { Eu envio a Ele com toda a sujeira } \\ \text { Gott sei dank der Paff ist Weck } & \text { Graças a deus o (padreco) saiu } \\ \text { Schlag Sie tot die Paffenhünde } & \text { Mate (à pauladas) os (padrecos cachorros) } \\ \text { Diese Raubtiere Vagabunde } & \text { Estes predadores vagabundos } \\ \text { Hab' i noch ni alles gesagt } & \text { Ainda não disse tudo } \\ \text { Adolf Hitler es sagen mag } & \text { Adolf Hitler o deve dizer } \\ \text { Wenn Er mich dafür will Lohnen } & \text { Se ele me quiser por isto recompensar } \\ \text { Brauche ich kein Palast bewohnen } & \text { Não preciso nenhum palácio habitar } \\ \text { Geb' Er mir nen Pfaffen aus (ans) Papier } & \text { Me livre ele dos padres de papel } \\ \text { Nen' Gummi dran das auf der Brust } & \text { Da borracha sobre o peito } \\ \text { Der Pfaffe bammeln kann nach lust } & \text { O padre "copula" quando quer }\end{array}$

16 Tradução do alemão para o português feita por Eduardo Engelsing Marcant. (1999) 
Dat will i haben weiter nischt.

Schade das die G'schicht schon aus ist.

Dank voraus Hochachtungsvoll

Ihr kleiner Freund

T. R.

der "Truxa"
Isto eu quero ter, nada mais.

Pena que a história já acabou.

Agradeço em antecipação

Seu pequeno amigo

T. R.

o "Truxa"

A chinella irá e terá a benção do papa, mas é a minha que vae. O resto entrego a ti Vianna e a vos todos, creio, para maior brilhantismo da cerimonia arranjar uma pseudorevolta e depois envia uma cópia desta que por falta de papel não pude tirar.

Ando Seboso e tenho vontade de sahir quando vão me tirar daqui?

Creio que já tem confiança bastante em mim e os bensedores não farão nada a mim. Vou metter uma carta pedindo um padre para me confessar, etc. Sou por enquanto teu (inimigo)

Vae uma respectiva dedicatória, e tudo o mais, precisa ser digna de grande chefe.

$\mathrm{Na}$ voz do Upa eu tinha, agora, que avisar

\section{CARTA 5 (original)}

Seiner Excellenz

Herrn Adolf Hitler

Dieses ding ist für den Mann

Der diesen Schlappen tragen kann

Er hat Ihm gekrieg den Pfaffen

Weil Er dat Biest konnte Affen

Ich schick es Ihm mit allem Dreck

Gott sei dank der Paff ${ }^{17}$ ist Weck

Schlag Sie tot die Paffenhünde

Diese Raubtiere Vagabunde

Hab' i noch ni alles gesagt

Adolf Hitler es sagen mag

Wenn Er mich dafür will Lohnen

Brauche ich kein Palast bewohnen

Geb' Er mir nen Pfaffen aus (ans) Papier

Nen' Gummi dran das auf der Brust

Der Pfaffe bammeln kann nach lust.

Dat will i haben weiter nischt.

Schade das die G'schicht schon aus ist.

Ehr"werden können Sie mich verzeihen?

Mich verführt haben die Pfaffenschafte ${ }^{18}$.

Was hätte ich getan?

Wenn ich zur letzten Stunde Gott

hätte gesagt

tu es nicht du bist auf falschen (tradução)

Sua Excelência
Sr. Adolf Hitler
Esta coisa é para o homem
Que pode trazer este (pano)
(Ele o enganou o padreco)
Porque ele pode enganar a Besta
Eu envio a Ele com toda a sujeira
Graças a deus o (padreco) saiu
Mate (a pauladas) (os padrecos cachorros)
Estes predadores vagabundos
Ainda não disse tudo
Adolf Hitler o deve dizer
Se ele me quiser por isto recompensar
Não preciso nenhum palácio habitar
Me livre ele dos padres de papel
Da borracha sobre o peito
O padre "copula" quando quer
Isto eu quero ter, nada mais.
Pena que a história já acabou.
Excelência, poderia me perdoar?
Os padres me seduziram, o que eu/
O que eu poderia fazer?
Se eu na última hora deus
ivesse dito
não faz isso tu estás no caminho falso

17 "Pfaffen" é "Weltgeistliche; (heute abwertender) Geistlicher" (WAHRIG, 1980, p. 983), portanto é mesmo o que chamaríamos de "padreco", em tom pejorativo. Porém "Paffen", que ele usa duas vezes é, por assim dizer, soprar a fumaça de cigarro ou charuto com barulho, isto também "Paff". (Nota do tradutor) Existe a possibilidade de esquecimento do " $\mathrm{f}$ " para ficar "Pfaff". Mas também, como se vê na análise do caso, o autor fazia trocadilhos e era irônico em muitas passagens de suas cartas, dando a entender, metaforicamente, o que havia acontecido sexualmente entre ele e o padre. Desta forma, o trocadilho entre charuto/cigarro/fumaça e "padrecos" possui um sentido.

$18 \mathrm{O}$ termo alemão para clero é Pfaffentum. A palavra Pfaffenschafte inexiste no Hochdeutsch (a língua padrão). Optamos pela tradução padres e não clero, por parecer-nos que TR quis referir-se a um número grande de indivíduos, não porém ao todo da corporação. $\mathrm{O}$ uso do termo verführt e o profundo tom de arrependimento moral que o autor confessa endossam a conotação sexual do relato que a nossa interpretação defende. (Nota do tradutor) 
weg geraten. Ich Hochwürden wollen gnädigst mir einen Beichvater senden, werde alles beichten, habe jetzt noch etwas bange, aber vielleicht tue ich es schriftlich,/ ich glaube

es wäre besser denn so hätte die Kirche/ documente

um Ihre ${ }^{19}$ feinde niederzerschmettern. Warte/ aber geduldigst auf Euern befehlt.

Glauben Excellenz na mir, haben

Sie einen aufrichtigen Freund gefunden der die/ Wahrheit liebt

Euer Hochwürden

Freuer Freund

T. R.

P.S. Excellz. werden verzeihen dieses papier/ gesandt zu haben. Mich dringt die innerliche/ Not.

Sonntag, den 27. Juni 1937
Eu excelência gostaria de

enviar-me por caridade um confessor, confessarei tudo, tenho agora um pouco de medo, mas talvez eu faça isso por/ escrito, eu acho seria melhor porque assim teria a Igreja/ documentos (registros)

para aniquilar (esmagar) os Seus/ inimigos. Mas espero com a máxima/ pela Sua ordem.

paciência Acredite Excelência em mim o Senhor encontrou um sincero amigo que ama a/ verdade

Sua Excelência

Alegre amigo

T. R.

P.S. Excelên, queira me desculpar por/ ter-lhe enviado este papel. Em mim/ urge uma necessidade interior. Domingo, 27 de junho de 1937

Para que esta “confissão" seja compreendida em seu sentido mais amplo, segue-se o pensamento do psiquiatra suíço Carl Gustav Jung:

Em muitos casos psiquiátricos, o doente tem uma história que não é contada e que, em geral, ninguém conhece. Para mim, a verdadeira terapia só começa depois de examinada a história pessoal. Esta representa o segredo do paciente, segredo que o desesperou. Ao mesmo tempo, encerra a chave do tratamento. É, pois, indispensável que o médico saiba descobri-la. Ele deve propor perguntas que digam respeito ao homem em sua totalidade e não limitar-se apenas aos sintomas. Na maioria dos casos, não é suficiente explorar o material consciente... (JUNG, 1984, p. 44).

Mesmo que se fale aqui em aspectos psicológicos, a narrativa de Theodoro nada deixa a desejar a muitos escritores do período. E muito embora fosse considerado apenas um louco, e tivesse sido trancafiado em hospício por sua família, sua escrita simbólica e plena de sensibilidades de uma época revela circunstâncias, demonstra práticas de exclusão - social e cultural - tanto da parte da ciência médica de então como de sua família. Como podia seu pai e sua mãe não entender que ele sofria e que queria ser muito mais do que estava fadado a ser? Afinal, ele queria ser escritor e historiador, como de depreende de uma outra missiva, escrita ao General Flores da Cunha:

\section{CARTA 7}

Ilmo Sr. General

José Antônio Flores da Cunha

D. D. Governador do Estado

Porto Alegre

Saudações,

Tem a presente o fim de hippothecarvos a inteira solidariedade deste vosso humilde e obscuro soldado, que já na revolução de trinta marchou nas fileiras do exército da liberdade.

19 A forma do possessivo ihre (suas, seus) poderia referir-se tanto a Hitler quanto à Igreja. Sabemos referir-se ao primeiro pelo uso epistolar da maiúscula, quando o remetente refere-se ao destinatário. (Nota do tradutor) 
Outrossim trago ao vosso conhecimento - conforme documentos juntos, que no meu obscuro modo de pensar poderão ser de utilidade para concorrer à victoria da causa da nação, de qual sois nesta hora legítimo pioneiro e expoente máximo da vontade da nação desejando apontar-vos os erros políticos do clero, que por intermédio de sua ingênua mas nefasta acção arruina indivíduos e leva à divergência toda uma nação e conforme attesta a história, desde remotos tempos, o mundo inteiro.

Já Napoleão em carta dirigida a um Superior da Igreja, no ano de 1796, acusava-a de perturbação da ordem interna de seu paiz, ameaçando confiscar-lhe os bens, caso se repetissem tais desordens, promettendo, ainda, tocar os responsáveis cidade afora.

Conheceis sobejamente a história e, para não vos roubar inutilmente vosso precioso tempo não me servirei de outro argumentos, senão as cartas adjuntas.

Quer vosso soldado demonstrar ao seu recto e bravo general que, como sempre, sabe ser disciplinado e pede-vos, o indispensável apoio moral e material e vossas ordens para o porvir.

Como podeis deduzir pelas provas juntas está tudo prompto $\mathrm{p} / \mathrm{a}$ batalha esperando tão somente vossa autoritária voz de comando. Aproveito a oportunidade para subscrever-me. De V. J.

Humilde Amo.e venerador

T. R.

Hospital São Pedro, 7 de julho de 1937.

PS: Rogo desculpar-me V. Excia o feitio desta que é cara como tudo, aqui no hospital, onde estou e tenho que lutar com sérias dificuldades para adquirir um pouco de papel e tinta na altura, pois creem que sou maníaco.

Preocupado que era com a situação do Brasil, escreve mais adiante em sua internação sobre o futuro do Brasil. Porém, retomando sua sensibilidade a respeito de sua doença e de sua família, memórias estas iniciadas na carta de número 1, a carta de número 11(escrita pouquíssimos dias antes da alta hospitalar) explícita também estas questões:

\section{CARTA 11}

À imprensa

Meditações e previsões sobre o futuro

O futuro é coisa que mais curiosidade nos desperta. Fica-se satisfeito quando, embora não acreditando na cartomancia, a cigana à qual damos um nichel, mais para ajuda-la que para nos dizer a tal tão tradicional sorte, diz uma porção de coisas entre as quais sempre uma ou outra é acertada. Geralmente nos contam coisas bôas. Mas a mim não interessa tanto saber algo do meu futuro individual e sim o futuro dos meus filhos e da humanidade. As cartas das quais leio esse inconfundível e inevitável porvir são as circunstâncias, que nunca enganam de um todo.

Vejamos: há 400 ou 500 anos atraz não se conhecia outro sistema de fabricar meias senão a mão; não se fabricava calçados senão a mão, etc. Hoje existem machinas que manejadas por um só indivíduo, produzem em 20 minutos 24 vezes mais que uma pessoa antigamente fazia trabalhando de sol a sol.

Deste e outros fatores podemos deduzir, sem receio de errar, que o mundo está no apogeu do desenvolvimento, se bem que quais diariamente surgem novidades no terreno da machinica, chimica, etc. Aquillo que serviu perfeitamente há 20 ou 30 anos, foi suplantado por coisa melhor, de mais rendimento sob qualquer ponto de vista, e o que hoje julgamos insuperável amanhã será superado e nos então exclamamos admirados: ora veja só!...

O mundo corre para frente, como cafre atacado de hydrophobia. O capital aumenta e se funde em emprezas poderosas: Institutos, Soc. Comm., e indústrias, que eliminam, quasi por completo hoje e completamente amanhã, a concorrência, de capital individual na proporção que a machina está por um só indivíduo. O plantador, como diz Remy Fonseca, é obrigado a utilizar-se do capital, hypothecando-lhe o produto que ainda está por nascer e para isso é obrigado pelas circunstâncias. Os “juros” que paga são elevadíssimos, além de arrumar fora disso a 
cangalha, que lhe serve para o transporte nas pessimíssimas estradas de nossa terra, resultando disso um duplo prejuízo (mas aparente). Relatividade!...O capital, como já disse, se une e reune e tornará a se reunir até que teremos no Brasil a completa eliminação da classe média como nos E. Unidos. (Sei de um homem que saiu há cerca de vinte anos do Brasil com trezentos contos do bolso perdendo tudo nos E. Unidos. Há 2 anos mandou para cá um seu filho para estudar a situação do pequeno industrialista aqui, a fim de tornar possível seu retorno, mas até hoje ainda não veio.) Existirá somente o operário e o grande capitalista, e até entre o primeiro existirá ainda, a concorrência individual, pois que as grandes empresas serão tantas que se estabelecerá a concorrência, como entre duas pessôas, obrigadas, de um lado pela necessidade, de outro pelo herdado egoísmo e fome ao poder, a suplantar a querer ser melhor enfim...

Se o mundo continuar nesta marcha a hecatombe universal é inevitável. Uns devorarão aos outros, como lobos famintos...Vianna Moog disse: "No Brasil tudo muda, ninguém se entende e tudo vai bem!" O que se dá no Brasil dá-se com a maioria dos paizes. Nem o facismo, nem comunismo, nem ismo nenhum dará ao mundo a prosperidade se os povos não se convencerem de seu egoísmo. Comunismo e facismo não passam de um jogo passatempo. Onde surge o comunismo surge o anticomunismo. Onde surge o nazi e o fasci surge o adversário. Poderão nascer destas "creanças" quantas quizerem, nada adiantará...O Brasil deve e está deixando de coxilar naquella confiança inerte de que amanhã descobriremos um homem que pagará as dívidas do paiz, com seu bom governo. No Brasil tem de tudo menos união, e somente esta poderá salvá-lo de sua ruína completa. Deus foi brasileiro e ainda é, mandando que o vento nos apanhe a lenha e derrube caixos de bananas, que nem nos damos ao trabalho de ajuntar, prevenindo-nos para o futuro...Tomemos como exemplo a Itália, cujo povo para ajudar as custas da guerra à Abissínia, sacrificou parte de suas jóias...

Se dissermos hoje ao povo: o Brasil precisa de um auxílio semelhante para arrumar-se a fim de se tornar uma potência que impõe respeito, as grandes massas nos chamarão de idiotas. O Brasil tem necessidade premente disso, se quer ter a mesma sorte da Abssínia.

Se o Brasil se arrumar, automaticamente se arrumarão os demais paízes sulamericanos isso é tão lógico como um e um, são dois. As bôas relações diplomáticas depois serão a fortaleza do continente sulamericano, que impedirá a invasão completa do extranjeiro, pois que a financeira é um fato que não podemos omitir. Não precisamos de armamento p/ uma guerra, que é difficil sahir, dada a índole pacifista e soberanamente diplomata do nosso povo, mas tão somente para dar um golpe de diplomacia no extranjeiro que nos explora e vai lentamente se apoderando do país. O golpe segundo a minha opinião seria o mesmo de Hitler, com relação às dívidas de guerra, pois que nós pelo caminho que vamos só temos que nos enterrar mais em dívidas e se não me trae a memória o Brasil já fez até um empréstimo para pagar os juros dos E. Unidos. Ora se é assim! Quem empresta para pagar juros, está na situação de pagar juros sobre juros. Para que dizer mais? Todos nós sabemos disso. O que acho motivo de sérias aprehensões é que relativamente pouco tem sido feito para melhorar a situação ruinosa do país de nada vale. O único valor é o de ganhar tempo e mais cousa alguma.

Aproveito ainda a estadia aqui no hospital para escrever algumas ideias e considerações porque sei estas estão tendo bôa aceitação junto ao meio literário e autoritário do meu país por partirem de quem tem relativamente pouca cultura. Admiro- me as vezes que ainda há pessôas que me olham como quem está deparando com o milagre do século. Ora sabemos que destes pequenos milagres há milhões mundo afora, mas que não tem a petulância de se prevalecer da bondade e paciência de seu proximo como faço eu. Continuarei apezar, a escrever sei que contribuo com as minhas modestas linhas para a obra dos que pensam com sensatez nos problemas da atualidade mundial...Se os pequenos pensam como os grandes é signal seguro de que ambos estão certos. Disse que escreveria enquanto estou aqui porque em casa não poderei faze-lo, devido que pae mãe esposa irmãos se

(estes dois pedaços de carta foram encontrados isoladamente, escritos em papéis diferentes, e depois juntados neste trabalho pelo contexto)

anteporem a mim como uns endemoniados por julgarem que estou louco.

Meu pae esteve aqui me visitando no sabbado passado. Eu querendo conseguir mais liberdade em casa, disse-lhe em resposta a sua pergunta se já tinha deixado a mania de escrever que 
se era loucura porque não me deixa esta. Foi quanto bastou para que pouco depois sahisse... almente se despediu de mim. Para mim acho que esta contrariedade até é uma vantagem, pois que tenho notado, quando me incomodam, tenho até mais inspiração. É verdade que as vezes desanimo um pouco e não faltava muito me convencer da minha loucura...

A minha vida até hoje foi, nada mais, nada menos que um rosário de contrariedades deste quilate.

Sahi da sociedade que tive com meus irmãos porque estes se opunham ao meu plano de fabricar o pão com fermento Fleischmann, que naquella epocha estava sendo introduzido, com verdadeiro bombardeio de reclames. Conheço sobejamente a história do judeu, e pude avaliar que o fermento Fleischmann iria ser introduzido sem a menor dúvida. Ora, a casa teria soffrido um grande impulso progressista se fôssemos um dos primeiros a melhorar o artigo. Mas qual quem foi que disse que eu convencia os meus desta vantagem... A saboaria da qual faço parte nasceu da minha ideia. Todo o melhoramento da fabricasinha etc. (não exagero). E um dia o meu pae poz na mesma meu irmão (o mais moço da família) e pouco tempo depois por ocasião de uma forte crise de negócio (saboaria é um péssimo negócio) recebi estupefato, a ordem de procurar um emprego. Eu, que comecei a fazer sabão em latas de queirozene em minha casa, passando pouco tempo depois a fazel-o em casa de meu pae, num tacho um pouco maior, fui o primeiro a ter ordem para dar um jeito na vida.

Verdade é que a fabricasinha foi montada com capital de meu pae, mas meu irmão também. Não entrou com cousa alguma. Eu não sou dos que vivem em desharmonia com seus paes. Desde os 14 annos, com exepção de dois annos, trabalhei sempre com e para meus paes.

Dos filhos, que o velho meu pae gosta menos, sou eu, mas felizmente a minha mãe é ma santa $\mathrm{p} / \mathrm{mim}$, mesmo que tenha que fazer o que lhe dicta o velho, tem agido $\mathrm{c} /$ muita habilidade, servindo sempre de mediadora. Se digo que meu pae é homem de má índole minto. É tão somente no systema de orientação que sempre divergimos. Mas o meu grande amigo é o futuro e eu confio plenamente nelle. Tenho esperança de sahir completamente curado deste hospital pois que a meu ver o factor máximo de minha moléstia é o excesso de trabalho physico e intellectual, para meu corpo enfermo, se bem que há outros factores. Enfim uma causa age sobre a outra resultando o desequilíbrio da saúde. Terei errado dizendo tudo isso? Pouco já me importa. Tive que desabafar uma vez o que me ia no íntimo, mesmo que isso seja erro. O meu estado de saúde tem melhorado muito graças a attuação por parte dos scientistas inclusive o director deste hospital e quando me lembro da possibilidade de minha completa cura, tenho vontade de ficar mais um ou dois annos, não obstante ter muita saudade de esposa e filho que vejo uma vez por semana.

De V.V.S.S. Humilde amigo

T.R. H.S. Pedro 02 de setembro de 1937

Para que sua narrativa faça sentido, em uma "comunidade de sentidos partilhados", passemos à memória e à visão de mundo de sua família, encontrada em pesquisa posterior na região metropolitana de Porto Alegre, cujos representantes atuais nada mais são do que seus próprios filhos e sobrinhos.

\section{A memória familiar - esquecimento, silêncio e rupturas}

Theodoro suicidou-se em 1938.

Esta constatação foi feita ao ouvir de Vilson, seu sobrinho, em 2007, uma declaração em voz quase inaudível: "Havia também o tio Theodoro, que se matou para o desgosto de nossa avó". ${ }^{20}$

20 O material relativo a esta parte da pesquisa, que inclui as entrevistas com várias pessoas vivas da família de Theodoro e muitas fotos de objetos seus, ainda está em compilação em sua íntegra para uma futura publicação mais completa sobre a vida e a obra de TR (Theodoro R.) 
Memória é um processo, onde se articulam afetos e representações; não existem memórias fora de um contexto afetivo. Ao concordar-se com a autora destas ideias (GONDAR, 2005), o significado de encontrar a família de TR renova-se e adquire um vulto grandioso, quase como as ideias consideradas delirantes que ela tinha em sua internação e que lhe renderam o rótulo de "parafrênico". Seria parafrenia o significado simbólico e real de suas narrativas? Era "mania de perseguição" tudo aquilo que ele percebia em seus irmãos e pai, ao não deixá-lo concretizar algumas ideias criativas na padaria e na saboaria da família?

E não é "grandioso" um historiador deparar-se com fonte de pesquisa tão ímpar e privilegiada quanto inusitada?

Atualmente, passados 74 anos destes escritos que se tem em mãos, suas ideias vieram à luz a partir de minha pesquisa e se pôde depreender um mundo raro de sensibilidades, que nada tem a ver com delírios e alucinações. Finalmente TR conquistou sua glória como escritor!

Seja através da memória (e dos silêncios) familiar, seja através da historiografia já existente sobre a história da loucura e das práticas de exclusão em nosso meio e no Brasil ${ }^{21}$, articulamos as narrativas de TR em novas narrativas, constituindo um processo que talvez nunca cesse, pelo significado que pode ter para nossa época pensar a sua época.

Sua família era de imigrantes, vinda de Lodz, Polônia, porém consideravam-se russos; ele suicidou-se dez meses após sua alta no hospital; morreu na Santa Casa de Misericórdia de Porto Alegre, para onde foi trazido depois de ter recebido dois tiros em Canoas (há a suposição que tenha sido assassinado, fato este que ficou em segredo de justiça, como consta em sua causa mortis no atestado de óbito). Seus ossos estão numa vala comum do cemitério Batista de Porto Alegre, denotando que ele foi "esquecido" pela família. Ele tocava violino. E tudo o que escreveu em suas cartas, tidas como delirantes pelos médicos de sua época, eram questões reais de sua vida. TR foi padeiro, saboeiro, trabalhou na fábrica de engarrafar bebidas de um parente. Nada disto era mentira ou delírio, e tudo isto já estava escrito nas cartas.

O avô de TR, assim como seus pais, nasceu em Lodz, cidade fronteira entre Polônia e Rússia, pertencendo a uma ou a outra conforme a data das disputas de fronteiras. Vieram todos para o Brasil, em um navio, fugidos da guerra, com imigrantes poloneses/russos em 1895, talvez todos no mesmo navio. O avô Karl T R (T é o mesmo nome próprio de TR) morreu no navio e foi atirado ao mar (segundo documentos, quando chegaram a Florianópolis). A mãe de TR, nascida Schindler, provavelmente conheceu O R, filho de Karl T $\mathrm{R}$, no navio, e casaram-se no Brasil, em Porto Alegre, em 1900. Há vários documentos e passaportes que confirmam estes dados. Tiveram quatro filhos homens que viveram, entre eles TR, e uma filha mulher (Olinda) morta com 1 ano e 9 meses.

Alguns entrevistados, familiares da geração de seus filhos e netos, relatam que seus pais (irmãos e cunhadas de TR) contavam que ele lia muito e escrevia demais nas bordas dos jornais, e que esta sua sensibilidade para leitura e escrita é que o fez se matar. Nenhum entrevistado mencionou a internação no HPSP, deixando-nos a "quase" certeza que os irmãos de TR, sua esposa e seus pais nunca falaram sobre isto com seus filhos e netos. E este "silêncio" familiar é muito significativo, como constata Pollack (1989), aqui podendo significar não um "esquecimento", mas sim um ressentimento, ou uma necessidade de não se confrontar com sentimentos ambíguos que a menção desta morte prematura (suicídio) traria à tona. Existem nas lembranças de uns e outros, zonas de sombra, de silêncio, de "não-ditos": "as fronteiras desses silêncios e "não-ditos" com o esquecimento definitivo 
e o reprimido inconsciente não são evidentemente estanques e estão em perpétuo deslocamento" (Pollack, 1989, p. 9).

Ao falar no suicídio de TR, todos aqueles que o mencionaram falaram em um tom de voz muito baixo ou então não o mencionaram espontaneamente. A discussão sobre o "tabu" do suicídio e da loucura, em uma família até aquele momento estruturada e unida, faz-se importante. Em nenhum discurso familiar houve a associação entre loucura e suicídio. Porém, alguns relatam o fato de TR ler e escrever muito como sendo um fator desestabilizante de seu estado emocional que o levou ao suicídio.

"Duas testemunhas nunca contam a mesma história e nenhuma história, ou memória, permanece para sempre a mesma" (SACKS, 2005) Foi exatamente assim ao construirmos mais um pouco da história/memória de TR e de seu mundo a partir das entrevistas familiares contemporâneas.

Seu filho E., nascido em 1936, tinha pouco mais de dois anos quando seu pai se matou. Retém em sua memória, porque lhe contado e porque sensível à sua representação, o dia do cortejo levando o corpo no cemitério, aonde ele ia atrás da fila, chorando muito e chamando o pai em alemão. Sim, pois TR ensinou alemão ao filho bebê, e ele só aprendeu português aos 4 anos, quando foi morar no interior do estado, com a família materna. Esta memória permanece viva em E., bem como tantas outras que carrega consigo: homem inteligente, sensível, tocava violino.

No momento desta primeira entrevista com o filho de TR, este mostrou-nos o violino que pertencera a seu pai no passado, estivemos com ele em nossas mãos. O suicídio foi mencionado aos poucos pelo filho, e foi explícito sobre isto somente quando perguntei sobre a causa da morte. Aliás, foi um segredo de justiça, existiu um processo, ao suspeitarem de homicídio, por ele ter dois tiros na cabeça. TR foi encontrado no mato atrás da casa da rua Araçá, em Canoas. Ele era 11 anos mais velho que a esposa e a amava. Deixou uma carta explicando os motivos da morte, onde tem até gotas de sangue. Esta carta estava com a esposa H. M., até sua morte. Observou-se, assim, que TR não teve sua memória maculada pela esposa.

Existe também a filha, Maria, que como se imaginava, estava sendo gestada quando TR cometeu tal gesto. Talvez ela, atualmente católica fervorosa, esteja de posse da carta suicida, bem como de muitos outros materiais, pois sendo mulher e morando com a mãe quase a vida toda, a intimidade de ambas deve ter as tornado cúmplices de revelações. Afinal, M. só conhece o pai pelas fotos e pela memória dos outros. Mas ela silencia muita coisa...

Ficou claro que os filhos não sabem da internação psiquiátrica, bem como os outros familiares, os quais nunca a mencionaram. Tampouco parecem desconfiar, pois se referem à causa da morte como um desgosto financeiro. Porém, a esposa de E., quando este saiu da sala, contou que em conversa com sua sogra (esposa de TR e mãe de E.), foi-lhe revelado que ele tentara matar-se mais de uma vez.

Comprovamos aqui o fato de TR não escrever delírios ou fantasias em suas cartas - não poderia ser isto razão para mantê-lo como um louco internado em um manicômio. Muito do que relatava sobre si era verídico (saboaria, padaria, a briga com irmãos). Mais motivos ainda têm-se para ver que ele falava a verdade, não era um louco e sim um homem que parecia não ter achado seu lugar no mundo, ou sofreu por outro motivo... Seu filho conta que ele era inteligente, e que escrevia em alemão. Tocava violino na orquestra de Porto Alegre, uma precursora da OSPA. Sua sensibilidade, marcante e viva, mostra-se nas palavras e na memória de seu filho: conta que seu pai pediu à esposa que desse o violino ao filho e que nunca o deixasse vendê-lo, pois nunca ninguém daria o real valor que ele tinha... O valor do dinheiro não valia o valor daquele instrumento para ele. 
Sua filha, M., uma senhora de 70 anos, pediu para desligarmos o gravador quando ela nos deu a única informação que não tínhamos ainda: sua mãe dizia que TR saiu da sociedade da padaria da família por causa de uma "sabotagem" dos irmãos; mas que os primos ficam brabos, dizem que é invenção da mãe dela, esposa de TR (isto confirma o que TR escrevia nas cartas). A provável causa do suicídio seria, assim, a briga com os irmãos e o descontentamento em que vivia na sociedade com estes e o pai. Deu alguns detalhes, poucos, sobre isto. Enfim, ela foi a única que não nos mostrou fotos, documentos, etc. e disse que não os tem. Mas se desconfia que ela os tenha, sim, mas não quer mostrar. Ao mesmo tempo, parece que a questão da internação no hospício ninguém sabe mesmo.

No meio de tantos silêncios, as cartas dele confirmam o que a mãe dela disse, a grande amada de TR: houve brigas familiares e ele ressentia-se muito disto. Há mais coisas escondidas, percebe-se, do que nos contam. Segredos familiares, ressentimentos, que perpassaram as gerações. Nota-se a desagregação da família como um todo, pois embora saibam uns dos outros, há um ramo que vive em Brasília (GO), um em Sapucaia do Sul (RS), outro em Canoas (RS), e mais um em Porto Alegre (RS) - tendo, recentemente, a família de Sapucaia encontrado a família de Brasília pelo Orkut. Vale notar que estes "ramos" referem-se aos filhos de TR e aos filhos de seus irmãos, portanto um parentesco bem próximo (primos em primeiro grau).

Embora Pollak, em seu texto, remeta a exemplos de um contexto coletivo e social mais amplo, suas reflexões sobre silêncio e memória são pertinentes também a casos individuais e de cunho familiar, adequando-se a caso específico de história e memória familiares, quando diz:

\begin{abstract}
A fronteira entre o dizível e o indizível, o confessável e o inconfessável, separa, em nossos exemplos, uma memória coletiva subterrânea da sociedade civil dominada ou de grupos específicos, de uma memória coletiva organizada que resume a imagem que uma sociedade majoritária ou o Estado desejam passar e impor. Distinguir entre conjunturas favoráveis ou desfavoráveis às memórias marginalizadas é de saída reconhecer a que ponto o presente colore o passado. Conforme as circunstâncias, ocorre a emergência de certas lembranças, a ênfase é dada a um ou outro aspecto. Sobretudo a lembrança de guerras ou de grandes convulsões internas remete sempre ao presente, deformando e reinterpretando o passado. Assim também, há uma permanente interação entre o vivido e o aprendido, o vivido e o transmitido. E essas constatações se aplicam a toda forma de memória, individual e coletiva, familiar, nacional e de pequenos grupos. O problema que se coloca a longo prazo para as memórias clandestinas e inaudíveis é o de sua transmissão intacta até o dia em que elas possam aproveitar uma ocasião para invadir o espaço público e passar do "não-dito" à contestação e à reivindicação; o problema de toda memória oficial é o de sua credibilidade, de sua aceitação e também de sua organização (POLLAK, 1989, p. 10).
\end{abstract}

Percebeu-se uma modificação no discurso familiar e, portanto, deste "não-dito", com os sobrinhos de TR: Artur, e sua irmã, Mirna. A mãe deles, cunhada de TR, contava a seus filhos ainda crianças que TR passava as noites escrevendo em jornais, nas partes em branco das páginas; o neto de TR, filho de E., parece também sofrer de "manias de perseguição", como eles diziam do próprio TR. Foi a primeira vez que este assunto, "mania de perseguição" foi tocado mais às claras, mesmo não sendo falado sobre hospitalização alguma nem usando a palavra "doença" ou a expressão "doença mental". "Ele estudou muito, ele estudou muito, que enfraqueceu a cabeça e acabou com a vida dele", disse um deles, referindo-se ao suicídio do tio TR. A mãe referia que ele lia demais, e ele era uma 
pessoa que se impressionava com as coisas (SIC). "Por que tem o seguinte: ele era uma pessoa que se impressionava com o que lia; ele era muito inteligente e ensinou a vovó a ler". O suicídio foi um choque na família, e aqui ambos discordam quando a entrevistadora perguntou se eles se lembram, uma vez que eram crianças: ele (Artur) diz que não e ela (Mirna) diz que sim, que lembra do episódio e do que comentaram a respeito: "ele deu um tiro na cabeça lá na aeronáutica, e ninguém sabe a causa; ele era muito estudioso". Os filhos de TR são muito católicos (por parte da mãe) e o suicídio foi abafado na família. Artur é espiritualista e acredita que o espírito de TR já retornou e deve ser o filho de E. (portanto neto de TR e que também se chama E.): “ele repetiu o mesmo que a mãe contou sobre o tio TR; o tio gostava muito da nossa mãe, (...), a mãe contou que o tio TR falava muito, (...) ele ficava a noite toda escrevendo em todos os espaços em branco disponíveis dos jornais, e escrevia que ele era perseguido pela igreja, bispos, religiosos." Seu Artur acha que era na vida anterior, na Idade Média, que ele teria sido perseguido na Igreja. Afirma que o filho de E. é igual, pois vive dizendo que têm pessoas o perseguindo em seu emprego. Igual ao avô (TR), diz Mirna. "Ele é diferente dos outros primos, se esconde, vive se esquivando." "Tenho uma fotografia do TR, era bem simpático, bonito, as moças gostavam muito dele", disse Artur. TR escrevia muito, muito, muito. Pena que não guardaram seus escritos, disse Mirna. Memória esquecida, reprimida, sabotada, silenciada.

Artur se lembra da casa em Canoas, do vovô Oscar (OR), um casarão, todo avarandado, com árvores gigantescas, carro, muito grande e bonita. "Tinha uma biblioteca cheia de livros, e não falava muito com os netos. Atrás era a saboaria. Era enorme. A saboaria era somente do vovô. A padaria no início era do vovô, na Avenida Brasil, e depois passou por herança aos filhos (Arno, Alfredo e Oscar). Os irmãos se ajudavam muito. Sua mãe falava que TR era perseguido pelos religiosos e ficava surpresa em relação a isto. $\mathrm{O}$ pai deles (irmão de TR) também lia muito, tinha uma cultura vasta, não era tão reservado, mas também não falava sobre a história da família.

Esta última entrevista foi muito importante para nós, até para percebermos uma mudança no olhar familiar: inferem um caráter "hereditário" ou familiar de TR em seu neto. O que significa isto? Confirma-se que ele tinha "mania de perseguição", mas esta era devido a que?

Os familiares vivos mais próximos e mais velhos (filhos e sobrinhos), até onde se observou, não sabem que TR esteve no manicômio, tampouco sabem da existência das cartas que foram deixadas nos prontuários. Sua esposa, assim como seus pais e irmãos (três), que viveram muito tempo em companhia dos filhos e netos e morreram bem velhos, parecem não ter contado sobre a internação de TR no HPSP de Porto Alegre.

Sua história acaba no suicídio e em seus ossos no "valão" comum do cemitério Batista? Este silêncio seria por conta de um tabu e um segredo familiar que ninguém revela? Toca-se na noção de sensibilidade a respeito de uma vida humana, que traduz em sua trajetória (do hospício para o mundo) dor e sofrimento, bem como uma inadaptação aos parâmetros considerados normais pela sociedade, até culminar em seu ato suicida. Porém, sua literatura epistolar, reveladora das memórias retidas, ajuda a realizar este processo entre afetos e representações que dão o sentido deste conjunto de rememorações.

\section{Considerações finais}

A história de TR, embora trágica sob o ponto de vista humano, é fonte da esmeralda mais pura para o pesquisador e historiador da História Cultural, e porque não dizer, da literatura. Repleta de dobras, indícios, cacos e traços de um passado, individual, familiar 
e coletivo, ela traz à tona memórias, sensibilidade e representações de um mundo somente possível a partir da rememoração e do imaginário construído pelas perguntas do presente a estes personagens e membros do passado.

Como revela José Murilo de Carvalho (1994, p. 12), "um micro-fenômeno, carregado de cultura, de sentido, lhe permite, através de intrincadas conexões, chegar ao macro-social".

Sendo o imaginário a maneira pela qual as pessoas estruturam seu mundo e lhe dão significado, as narrativas de TR e as posteriores narrativas orais de sua família de descendentes emparelham-se e distanciam-se, ao mesmo tempo, em sentido: este é o caráter muitas vezes paradoxal da memória, ao comportar também silêncios, esquecimentos, lembranças reprimidas.

Tampouco TR saberia naquela época que sua visão de mundo, incompreendida incompreensão que possivelmente foi motivo de sua loucura e de sua morte - configura-se em um instrumento para analisarmos um processo mais amplo, sobre a sensibilidade de um mundo que exclui todo aquele que foge dos padrões da sanidade mental estabelecida pela medicina e pela própria sociedade.

Desde lá, do prontuário escondido, até agora, com o contato com a família, muitas coincidências aconteceram e parece, utilizando o recurso do imaginário, que TR realmente quer sair do anonimato. Este era seu grande sonho, pois ele tinha o que dizer ao mundo. Assim, temos TR de carne e osso mesclando-se com o TR personagem, e enquanto personagem ele tornou-se um operador de sensibilidades.

A partir das pistas deixadas por esta "literatura sensível da exclusão" e do material encontrado em seu prontuário, juntamente com o resgate da memória familiar re-traçamos a história de vida do personagem TR, desde seu espaço cotidiano até sua vida e morte na "vida real".

Deparou-se com conflitos de memórias: individuais e familiares, ditas ou silenciadas. Vilson (sobrinho) fala baixinho sobre o suicídio do tio, parecendo temer algo; E. (filho) desacredita no suicídio e prefere ficar com a hipótese de homicídio, dando muita ênfase aos dois projéteis encontrados, e tampouco revela a semelhança de seu filho com seu pai; M. (filha) pede que seja desligado o gravador e chama a atenção para o motivo do suicídio: uma briga em família; Artur (sobrinho) credita as intempéries de TR a vidas passadas, onde teria sido perseguido pela Inquisição; Mirna (sobrinha), induzida pela memória da mãe, enfatiza que ele escrevia muito nas margens dos jornais, trazendo os indícios mais fortes dos problemas emocionais que o afligiam. Mas, também, não se pode deixar de referir que todos foram unânimes em falar na inteligência aguda e na sensibilidade de Theodoro.

Teríamos o direito de inferir que a distância existente entre os quatro ramos familiares (filhos e netos de TR e de seus três irmãos) na atualidade, registrada por nós nas entrevistas, teria começado por este "racha" familiar do passado?

O que está em jogo na memória, como diz Pollack, é também o sentido da identidade individual e do grupo. Não sendo possível sustentar uma verdade apenas, as verdades subjetivas floresceram (SARLO, 2007, p.39), afirmando as sensibilidades de um indivíduo e de uma família, através de narrativas da memória e de narrativas da loucura - que nem sempre em conflito e muitas vezes cortando um silêncio familiar redimensionaram o passado.

Portanto, sua vida pode ter sido interrompida pelo tiro suicida, mas não o processo de sua memória, que se tornou individual e coletiva neste resgate.

Termina-se esta exposição das memórias de Theodoro, com um versinho escrito por ele, no dorso de um papel de propaganda de chocolates, em 1937, em seu quarto no hospital psiquiátrico. Testemunho simples e sensível, de sua alma paradoxal, atormen- 
tada e confiante num futuro, que existiu em sua imaginação e foi resgatado na narrativa histórica a partir do ano 2000:

\author{
(La vae um Judas) \\ O sino da igreja havia, \\ Recém dado meio dia \\ Sob o céu turvo cinzento \\ Dum dia nebloso, friolento \\ Passam, ante mim, carregando a cruz \\ Qual se fosse uma visão \\ As esposas de Jesus \\ Oh castos anjos da piedade \\ Tendes na fronte a luz da santidade \\ Num anhelo à outra vida; \\ A eterna, nunca vivida \\ E o sino havia \\ Recém dado meio dia... \\ Anunciamos aquela alma \\ Que renunciou com calma \\ Que inda mais pura \\ Soffre toda tortura \\ Da cruciante dôr \\ Dum grande amôr \\ E não se engana quem em Deus confia \\ (Pseudônimo) Ulysses Xavier do Rego
}

\title{
Referências
}

ARTIÈRES, Phillippe. Arquivar a própria vida. Estudos Históricos, Rio de Janeiro, v.11, n.21, 1998, p.9-34.

CARVALHO, José Murilo de. A Nova Historiografia e o imaginário da República. In: ANOS 90, Revista do PPG em História da UFRGS, Porto Alegre, nº 2, maio 1994. GONDAR, Jô. Quatro proposições sobre memória social. In: GONDAR, J.; DODEBEI, V. (org.). O que é memória social? Rio de Janeiro: Contra Capa, 2005

JUNG, Carl Gustav. O Homem e seus simbolos. Rio de Janeiro: Nova Fronteira, 1983. JUNG, Carl Gustav. Memórias, sonhos e reflexões. Rio de Janeiro: Nova Fronteira, 1984. HALBWACHS, Maurice. A memória coletiva. São Paulo, Vértice, 1990.

PESAVENTO, Sandra Jatahy \& LEENHARDT, Jacques (ORGS.). Discurso histórico e narrativa literária. Campinas, ed. Unicamp, 2000.

. Sensibilidades: escrita e leitura da alma. In: PESAVENTO, Sandra J. \& LANGUE, Frederique. Sensibilidades na História: memórias singulares e identidades sociais. Porto Alegre: editora da UFRGS, 2007.

POLLACK, Michel. Memória, esquecimento, silêncio. Estudos Históricos, Rio de Janeiro, vol.2, n.3, 1989, p.3-15.

RICOEUR, PAUL. A memória, a história e o esquecimento. Campinas : Editora da Unicamp, 2007.

SACKS, OLIVER. A paisagem dos seus sonhos. In: Um antropólogo em marte- sete histórias paradoxais. SP: Cia das Letras, 1995. 


\section{Conexão Letras}

SANTOS, Nádia Maria Weber. Histórias de vidas ausentes - a tênue fronteira entre a saúde e a doença mental. Passo Fundo: editora da UPF, 2005.

. Narrativas da loucura \& Histórias de sensibilidades. Porto Alegre: editora da UFRGS, 2008.

SARLO, Beatriz. Tempo passado: cultura da memória e guinada subjetiva. São Paulo, Belo Horizonte: Companhia das Letras/UFMG, 2007. 